TTR

Traduction, terminologie, re?daction

\title{
Zionist Ideology and the Translation of Hebrew
}

\section{Jeffrey M. Green}

Volume 13, numéro 1, 1er semestre 2000

Idéologie et traduction

Ideology and Translation

URI : https://id.erudit.org/iderudit/037394ar

DOI : https://doi.org/10.7202/037394ar

Aller au sommaire du numéro

\section{Éditeur(s)}

Association canadienne de traductologie

\section{ISSN}

0835-8443 (imprimé)

1708-2188 (numérique)

Découvrir la revue

\section{Citer cet article}

Green, J. M. (2000). Zionist Ideology and the Translation of Hebrew. TTR, 13(1), 81-93. https://doi.org/10.7202/037394ar

\section{Résumé de l'article}

Un aspect idéologique de la traduction — La langue d'écriture employée pour une oeuvre peut avoir une connotation idéologique, susceptible d'être perdue en traduction. Comme c'est le cas lorsqu'il s'agit de langues associées à des nationalités émergentes et plutôt restreintes, le choix d'écrire en hébreu moderne peut être lié à une idéologie nationaliste (le sionisme). Cet article soutient que la création de l'hébreu moderne est semblable à celle d'autres langues minoritaires, qui sont les langues maternelles de communautés relativement peu nombreuses, à la différence des quelques langues très largement répandues et non limitées à un seul pays. Le développement et l'usage d'une langue minoritaire sont l'expression d'une affirmation de soi qui entraîne un certain isolement. L'auteur étudie une oeuvre du romancier israélien Aharon Megged et fait état de la signification idéologique de la langue d'écriture (l'hébreu moderne) en tant qu'élément littéraire du roman. Il note les aspects de cette signification qui seraient gommés par la traduction et souligne que les traducteurs doivent être conscients de ce problème.
Tous droits réservés (C TTR: traduction, terminologie, rédaction — Les auteurs, 2000
Ce document est protégé par la loi sur le droit d'auteur. L'utilisation des services d'Érudit (y compris la reproduction) est assujettie à sa politique d'utilisation que vous pouvez consulter en ligne.

https://apropos.erudit.org/fr/usagers/politique-dutilisation/ 


\title{
Zionist Ideology and the Translation of Hebrew
}

\author{
Jeffrey M. Green
}

Ordinarily when one thinks about the properties of a text that are specific to the language in which it is written one thinks about the structural features of that language: phonology, morphology, syntax, and semantics. One also thinks about its culturally specific features, problems of intertextuality, etc. But one doesn't necessarily think of the ideological significance of the text's being in a certain language, both for the original writer and his or her primary readers in that language. However, this, too, is an aspect of a text that may be lost in translation, perhaps inevitably so if one is not aware of its presence.

In these remarks I focus on the ideological significance of a text's being written in modern Hebrew, and I suggest that it may be similar to that of being written in other minority national languages, as opposed to world languages, though I admit that this distinction cannot be hard and fast, and it does not have to do with absolute numbers. Indeed, languages such as Tamil, which may be spoken by hundreds of millions of people, can be viewed even by their own speakers as minority national vernaculars. Moreover, in one context a certain language, like German or Portuguese, may be viewed as a world language, and in another context, it may be seen as a minority national language. However, at the extremes, the difference between world languages like English and Spanish, as opposed to languages such as Finnish and Georgian, which are spoken by relatively small nations and little known outside them, is quite clear. 


\section{The Revival of Hebrew: an Ideological Decision}

While the status of some languages might be contested, no one would claim that modern Hebrew is a world language or deny that it is intimately connected with Zionism'. Now, since Jews have a long history of disagreeing deeply with one another, it is not surprising that there are many competing versions of Zionist ideology. However, it is generally agreed that Zionism includes the following elements:

1. redefinition of the Jews as a nation rather than as a religious community;

2. the return of the Jews, as a nation, to their ancestral land; of the Jews.

3. the revival of the Hebrew language as the national language

The use of Hebrew is central to the Zionist project of redefining the Jewish people. In fact, many people have gone so far as to speak of a nascent Hebrew nation, as distinct from the Jewish people. Their plan was to leap over long centuries of humiliation in exile and link up with the heroic national past.

Incidentally, it might be argued that the revival of Hebrew has been superfluous, since the Jews already had a number of languages of their own. There was Yiddish, a highly developed language with a rich literary tradition and an active international press, spoken natively by millions of Jews in Eastern and Central Europe, with many other speakers in North and South America. There were also Ladino (a dialect of Spanish spoken by the descendants of the Jews who were expelled from Spain in 1492), varieties of Judeo-Arabic, Judeo-Persian, and even a dialect of Aramaic preserved by the Jews of Kurdistan - to mention but a few. Hebrew has been able to supplant these languages because it was not associated with the humiliation of exile and dispersion, but also because

\footnotetext{
${ }^{1}$ For a useful introduction in English to some of the literary issues involved in the revival of Hebrew, see Robert Alter, The Invention of Hebrew Prose: Modern Fiction and the Language of Realism (Seattle and London, University of Washington Press, 1988). For a comprehensive treatment of the national effort to revive spoken Hebrew, see Shlomo Karmi, 'Am Ehad Vesafa Ahat (Hebrew: "One People, One Language") Tel Aviv, Ministry of Defense Publishers, 1997.
} 
it was not associated exclusively with any one ethnic faction within the Jewish people.

As with the establishment of all vernaculars as official national languages, decisions had to be made as to correct pronunciation, levels of speech, the means of creating new words and expressions, and the like. All of these decisions are laden with ideological significance. For example, should Hebrew coin words from its own lexical resources or should it borrow words from other languages? Is the model for correct Hebrew to be found in the Bible, in ancient rabbinical texts, in medieval works, or elsewhere? The answers one offers to these questions are closely related to one's ideology regarding the nature of Jewish nationalism.

\section{Modern Hebrew: One of Many Revived Vernaculars}

Jews and Israelis like to think that the story of the revival of Hebrew is absolutely unique in human history. However, in the past two centuries, many vernaculars have been consciously adapted, as a matter of national ideology, for use as an idiom to express the intimate national sentiments of an oppressed or emergent national group, as well as to serve as a vehicle for the integration of that national group into modern life and the wide world as a nation with status equal to that of other nations. In many respects the ideological significance of modern Hebrew for its speakers is probably quite similar to the significance of other languages spoken by national minorities who have gained independence from empires - such as Greek, Hungarian, and Bulgarian.

To some degree the result of these successes is paradoxical. Literary and other cultural use of a revived national vernacular gives members of the national group the satisfaction of feeling that they are on an equal footing with speakers of majority languages. However, the development of a small national language is a matter of self-assertion that also leads to isolation. While it is a source of pride to know that one can write an article in modern Hebrew or Bulgarian about the most advanced aspects of social thought, for example, the scholars who write such articles are concerned to have them read internationally.

Academics all over the world confront the choice of whether to write in their own language or to write in some more widely known 
language such as English or French, and this choice is available to novelists, playwrights, and poets as well. It is important to bear this in mind, for the ideological significance of any act is enhanced when it is viewed as a matter of choice. Initially the educated people who wrote in their revived national languages, or who contributed to the revival of those languages by writing in them, had the option of using a widely known literary language but chose not to. By writing in Hungarian, say, rather than in the official German of the Hapsburg Empire, people chose to reinvent themselves, as it were, in the revived vernacular and express that reinvented self rather than translate it. Almost all the writers in Hebrew before the mid-twentieth century were at least bilingual and could easily, even profitably, have written in a more widely known language. And they were not alone in this. Ideologically motivated language choice is not always a movement from a world language to a minority national language like Czech, Georgian, Rumanian, Bengali, or Catalan. A Polish sea captain and an exiled Russian aristocrat, as well as various Czech exiles have chosen to express themselves in English. A major twentieth century French playwright was originally Rumanian, and so on.

\section{The Intimacy of a Small Language Community}

While use of a minority language is an intentional act of self-assertion, directed outward toward other nations, it also creates an intimate realm of discourse. Writing in Gaelic or Welsh or, perhaps to a lesser degree, because they are relatively transparent to those who know other Romance languages, Catalan or Provençal, you are addressing a private audience and speaking behind the back, as it were, of majority language speakers.

Not only did the use of Hebrew create a private realm, largely inaccessible to outsiders, it also created its own audience, the Zionist reading public, as opposed to traditional religious Jews, who knew only biblical and rabbinical Hebrew, or assimilated Jews, who knew no Hebrew at all. Even today, when there are a few million native Hebrew speakers, who use the language not by choice but because it is more or less the only one they have, the reading public addressed by a Hebrew writer remains far less amorphous than the reading public addressed by a writer in languages that are used by more than one nation in more than one place. Needless to say, this privacy disappears when a text written in a minority language is translated into a world language. 


\section{Translation from a Minority Language to World Language: A Practical Illustration}

In translation neither the national-cultural self-assertion of the original text is apparent, nor the intimacy of private communication, as I shall show by considering a concrete example. As we pass from the theoretical to the practical plane, I would like to emphasize that in one sense of the word, "theoretical," the problem I am addressing remains theoretical: I have not been asked to translate the book in question.

Aharon Megged, who has been one of Israel's leading novelists for several decades, recently published a novel entitled Dudaim Min Haaretz Hakedosha, the literal meaning of which is, "Mandrakes from the Holy Land"2. The title itself is illustrative of the problem facing the translator, because it isn't idiomatic Hebrew. Instead of the ordinary phrase, "eretz hakodesh," which can be literally rendered as "the land of holiness," Megged translated the English expression, "the Holy Land," back into Hebrew. This is because the entire book is presented as if it were originally written in English. It consists of the fictional journals, notebooks, and correspondence of an English traveller, ostensibly written in 1906. The implied Hebrew author of the book is in effect its fictional translator into Hebrew.

Megged's main protagonist is Beatrice Campbell-Bennett, whom he describes as a fat lesbian and who has come to Palestine, still under Turkish rule, with a religious and artistic mission, for she is both a devout Protestant and a graduate of the Slade academy of art. She has decided to make paintings of all the flowers mentioned in the Bible. This religious mission is tied up in her neurotic soul with unrequited love for Vanessa Stephen (soon to become Vanessa Bell), Virginia Woolfs sister. Thus the mandrake, an aphrodysiac root, is the essence of her quest (and of course, given Megged's irony, she is doomed never to find any).

In fact, her mission founders completely. She is raped both by her Arab guide and a Jewish settler, becomes pregnant, and settles in the Arab village of Majdal near the Sea of Galilee, the birthplace of Mary Magdalen, upon whom she has become fixated. Megged compounds the

${ }^{2}$ Tel Aviv, Am Oved, 1998. 
irony with which he treats his protagonist by inserting occasional comments by a grotesquely obtuse psychiatrist, a family friend who has been despatched to Palestine to save the heroine.

Because it is presented as a translation from English into Hebrew, the fact that Dudaim Min Haaretz Hakedosha was written in Hebrew is of unusual thematic significance. Thus it is a useful test case for demonstrating the ideological significance of the use of Hebrew and the problems this may pose for the translator.

Earlier I mentioned four ideological aspects of the use of modern Hebrew:

1. The intimate connection between Hebrew and Zionism;

2. The revived language as a vehicle for the integration of the national group into the wide world as a nation with status equal to that of other nations;

3. The use of Hebrew as a matter of choice;

4. The privacy of discourse created by using a little known language.

Let us look at Megged's novel through the filter of those four issues.

1. Dudaim Min Haaretz Hakedosha is clearly written within the context of Zionist discourse. Describing Palestine in 1906 from the point of view of this disturbed protagonist permits Megged to make several points that are of ideological significance in the context of current Zionist debate.

a) It allows him to portray the Land of Israel before it was transformed by the Zionist movement, supporting the Zionist claim that the land was underpopulated and underdeveloped. On the other hand, the land was also unspoiled back in 1906, and, like many veteran Zionists today, Megged is dismayed at the damage done to the ecology and the landscape by overzealous settlement. 
b) It allows him to portray Arabs from an apparently neutral perspective as tricky primitives, people who had no particular vision regarding the country.

c) In contrast, the Jews whom the heroine meets tend to be modern, well-educated, and idealistic.

d) Ironically, Britain, whom the main protagonist represents, is seen by the Zionists she meets in Palestine as the agent of enlightened progress, although Beatrice is a religious fanatic, and, of course, England came to play a controversial role in Zionist history after the British conquered Palestine from Turkey and received the mandate over the country from the League of Nations.

2. With respect to the literary use of modern Hebrew as a vehicle for the integration of the Jews of Israel into the wide world as a nation with status equal to that of other nations, this is a constant battle. Again and again Israeli writers must prove both to themselves and to the world that their work is worthy of international interest because of its literary merit. In fact, Megged, who is a master of fictional technique and a fine stylist, has never attained international recognition commensurate with his popularity and status in Israel ${ }^{3}$. Perhaps that is why Dudaim Min Haaretz Hakedosha is a particularly self-assertive work, a demonstration that Hebrew fiction can invade and conquer even the august precincts of the Bloomsbury Group.

3. As for Hebrew being Megged's language of choice, I don't know whether he himself, who came to Palestine from Poland as a child, was brought up knowing another language well enough to write in it. In any event, his personal decision to master the Hebrew language and to use that language to create rich works of fiction over a fifty-year career is emphasized here, with a degree of irony, in the decision to write as if he were translating from English. Not only does this presentation of the text underscore the voluntary nature of the use of Hebrew, the Zionist

${ }^{3}$ The Checklist of Israeli Literature, in English, 1948-1996 compiled by Irwin T. Holtzman (Bloomfield Hills, MI, Irwin T. Holtzman, 1997) lists only four novels of his in English translation, and no novel by Megged has been translated since 1982, though he has been quite productive in Hebrew in the past two decades. 
characters who appear in the novel are all native speakers of other languages, and the English narrator recognizes that their use of Hebrew is an idealistic act of nation-building.

4. Finally, regarding the privacy of communication between the writer and his primary reading public which is created by the use of a little known language, this, too, is quite evident in Dudaim Min Haaretz Hakedosha. In the intimacy of one's own private language, one can speak more freely both about others and about oneself than in a world language, in which one is likely to be overheard.

As I mentioned, the woman chosen by Megged to represent English culture could be described as troubled. Her father is a minor politician and inveterate womanizer, her mother is an alcoholic, and she herself is a psychologically unstable religious fanatic who goes over the edge at the end of the story. British readers would have to be very good sports indeed to accept this pathetic narrator or the obtuse psychiatrist who comments on her letters and diaries as representatives of their nation, when the author presenting that character is an outsider, as Megged is an outsider with respect to British society. However, writing in Hebrew for a private Israeli audience, Megged can say what he wants about the British, talking about them behind their backs, as it were.

\section{Translating Megged "Back" into English}

Now I suggest that we perform a thought experiment and imagine what ideological aspects of Dudaim Min Haaretz Hakedosha would be lost in the English translation.

\section{Removal from the Zionist Context}

First, "Mandrakes from the Holy Land" would be removed from its implicit Zionist context. As noted, in Hebrew this book can be read as part of the ongoing debate within the Zionist movement. To the degree that it is critical of Zionism, perhaps for betraying the idealism of the characters whom the narrator meets and for spoiling the landscape, this criticism is voiced in a Zionist context, as a polemic against certain currents of thought within the camp. As in any domestic quarrel, an argument used by one faction to attack its rival sounds quite different to both 
interlocutors when it is voiced by an outsider. In addressing Hebrew readers Megged implies that Zionism may not have turned out as well as its idealistic founders expected it to, a critique of Zionism that could be read as a constructive call for reform and renewal. Such a critique, when overheard in translation by outsiders, perhaps enemies of Zionism, could be construed as an attack on the very foundations of the movement. Conversely, being Zionist in its overall outlook, the book might arouse antagonism among opponents of Zionism abroad.

Actually, however, in English translation this book would probably not be seen in a Zionist context at all. Rather it would be read as a minor historical novel, probably arousing more curiosity in the English reader as to how an Israeli novelist viewed the British than about how he viewed a formative period in Zionist history.

\section{Loss of Audacity}

Second, Megged's use of Hebrew to represent texts purportedly written in English is, as I have noted, rather audacious, but this audacity would not be apparent in an English translation. Indeed the translator of this book into English would have rather a difficult stylistic task. Megged was not obliged to write in an authentic English style of 1906 . He merely had to remind us occasionally that the text was supposedly written in English. For example, he sometimes writes "yam hagalil", an unidiomatic calque of the English, "Sea of Galilee," instead of "yam hakineret," the ordinary Hebrew name of that body of water, which could be rendered, "the lyre sea." However, the English translator would have to produce authentic-sounding Edwardian prose. The translator's submission to a somewhat archaic model would probably sound more self-effacing than assertive.

\section{Loss of Literary Complexity}

Third, Megged's use of Hebrew to represent English also gives him a perspective on the novel, as its implied author, that would be lacking in an English translation. As noted, on her pilgrimage to Palestine, the heroine of "Mandrakes from the Holy Land," meets a number of early Zionist settlers, and she is impressed by their idealism, energy, and intelligence. She notes that they use Hebrew, and the power of this observation is enhanced by its being reported in the modern Hebrew that 
developed out of their efforts to revive the language. The subsequent transformation of the Jewish people in the Land of Israel into a dynamic nation is epitomized by the use of Hebrew to look back at the land and the people in the time before this transformation was effected. This triumphal view of the history of modern Hebrew would hardly be evident in English translation.

Most importantly from a literary standpoint, the fictional premise, that the novel was translated from English diaries and correspondence, creates a dual perspective that would be lost in an English translation back to the purported "original". A Jewish-Israeli-Hebraic-Zionist point of view is implicit in Megged's authorial strategy, since the action is viewed both by the heroine who reports it and also, implicitly, by the Hebrew "translator" who makes it available to the reader. The "translator," as I have mentioned, becomes the implied author. As a Hebraist he knows a great deal more about the Jews and Zionism than the narrator, and he knows he shares this knowledge with the members of his implied, Hebrew-speaking audience.

For example, Beatrice befriends the Aaronsohn family in Zikhron Ya'akov, a famous family of cultivated Zionist pioneers. Aaron (1876-1919) was an agronomist, and he takes Beatrice on a trip to gather plants. He also invites her to his home, and she even develops a crush on his younger sister Sarah (1890-1917). What Beatrice could not have known in 1906, but what every Hebrew reader knows today is that the Aaronsohn family established "Nili," a pro-British spy ring against the Ottomans during World War I, and that Sarah was captured, tortured, and shot herself to avoid further torments. The Aaronsohn family have entered Israeli folklore. Schoolchildren are often brought to see their house in Zichron Ya'akov, and schoolgirls identify with Sarah, who is the subject of popular biographies. In Dudaim Min Haaretz Hakedosha, Beatrice impulsively kisses the sixteen-year-old Sarah, who is nonplussed, as is the Israeli reader, for whom this is equivalent to having a character in a historical novel kiss Joan of Arc.

Because the implied author knows more than the protagonist who is telling the story, knowledge that is implicit in his use of Hebrew, the novel is infused with complex irony which is related to the assertiveness of Zionist ideology. This would certainly be hard to render in an English translation, the readers of which cannot be expected to have 
heard of Sarah Aaronsohn and Nili. An English reader might not even realize that the Aaronsohns are historical figures.

\section{Concluding Remarks}

The ideological significance of the text being written in its native language (whether or not this language is the author's native language) is a feature of literary works that tends to be ignored because it goes unseen. For readers of a work in the original language, this feature might be entirely self-evident, an expected part of the literary message. For readers of the work in translation, this feature may be entirely invisible, something inevitably lost in translation like intertextual references or the specific sonority of the original words.

Just as translators seek strategies to minimize other losses, they may also seek strategies to minimize the loss of ideological significance. However, in order to minimize a loss, one must be aware of it, and this was the purpose of the present paper, illustrated by an example from contemporary Hebrew literature, while showing that the Hebrew language is not unique in serving as a vehicle of literary expression laden with ideological significance.

In undertaking a translation of Dudaim Min Haaretz Hakedosha, to remain with our example, an imaginative translator might choose an intrusive strategy equivalent to Megged's role as the "translator" into Hebrew in order to preserve the complex perspective that energizes the Hebrew original. For example, the translator might masquerade as an Israeli historian who discovered these journals and letters. Then she could introduce notes and commentary similar to that of Megged's British psychiatrist - just enough to shift the proceedings into a new perspective.

However, such a strategy might prove cumbersome or overly intrusive, so the translator could preface the translation with a short note about Megged and modern Hebrew literature or simply let the book speak for itself and hope for the best. Ultimately, just as we can never hope to understand the Analects of Confucius as they were understood by their first generations of Chinese readers, we know that no literary work produced and received in one context can ever mean precisely the same thing in another. Awareness of difficulties does not always lead to 
solutions to them, but rather to appreciation of the complexity and diversity of imaginative writing.

\title{
Alma College of Hebrew Culture, Tel Aviv
}

\begin{abstract}
Zionist Ideology and the Translation of Hebrew - The language used by the author of a text may be of ideological significance, and this is a feature that may be lost in translation. As with many languages associated with relatively small, emergent nationalities, the choice to write in modern Hebrew may be related to a nationalist ideology, in this case, Zionism. This article maintains that the creation of Hebrew is similar to the creation of other minority languages, whose use is restricted to a relatively small population of native speakers, as opposed to world languages, widely known and used by people of many countries. The development and use of a minority language is an expression of selfassertion that entails a degree of isolation. This article examines a novel by a contemporary Israeli novelist, Aharon Megged, and explores the ideological significance of its being written in Hebrew as a literary feature of the novel. It notes the aspects of that ideological significance that would be lost in translation and suggests that translators should be aware of this issue.
\end{abstract}

RÉSUMÉ : Un aspect idéologique de la traduction - La langue d'écriture employée pour une œuvre peut avoir une connotation idéologique, susceptible d'être perdue en traduction. Comme c'est le cas lorsqu'il s'agit de langues associées à des nationalités émergentes et plutôt restreintes, le choix d'écrire en hébreu moderne peut être lié à une idéologie nationaliste (le sionisme). Cet article soutient que la création de l'hébreu moderne est semblable à celle d'autres langues minoritaires, qui sont les langues maternelles de communautés relativement peu nombreuses, à la différence des quelques langues très largement répandues et non limitées à un seul pays. Le développement et l'usage d'une langue minoritaire sont l'expression d'une affirmation de soi qui entraîne un certain isolement. L'auteur étudie une œuvre du romancier israélien Aharon Megged et fait état de la signification idéologique de la langue d'écriture (l'hébreu moderne) en tant qu'élément littéraire du roman. Il note les aspects de cette signification qui seraient gommés par la traduction et souligne que les traducteurs doivent être conscients de ce problème. 
Keywords: translation, ideology, Hebrew, Zionism, Aharon Megged.

Mots-clés : traduction, idéologie, Hébreu, Sionisme, Aharon Megged.

Jeffrey M. Green : 3 Avigay: 1 Street, Jerusalem, Israel.

E-Mail : msgreen@mscc.huji.ac.il 